\title{
TOXICOLOGICAL EFFICACY OF PINUSROXBURGHII SARG. AGAINST WATER BORNE PATHOGENS
}

\author{
Ravikant Singh ${ }^{1}$, Ramesh Chandra Mishra ${ }^{2}$, Bhasker Jyoti', \\ Rohit Kumar Mishra ${ }^{3}$ and Manish Agrawal ${ }^{*}$
}

\begin{abstract}
${ }^{1}$ Department of Biotechnology, Swami Vivekanand University Sagar-470228, M.P. (India).
${ }^{2}$ Department of Agricultural Science, Mahakaushal University, Jabalpur-482003, M.P. (India).

${ }^{3}$ Centre of Science and Society, IIDS, University of Allahabad, Prayagraj-211002, U.P. (India).
\end{abstract}

\section{Research Paper}

\section{ABSTRACT}

The present investigation focused on the toxicological efficacy of essential oil of Pinus roxburghii Sarg. The oils were extracted from the leaves using hydro-distillation method. Further its toxicological efficacy was evaluated against Escherichia coli (MTCC-723),Klebsiella pneumoniae(MTCC No. 4032),Salmonella typhimurium (MTCC-3231) and Vibrio cholerae (MTCC-3906). Toxicological efficacy of essential oil was found highest against S. typhimurium. Inhibiting activity was also found against K. pneumoniae and E. coli (MTCC-723). Least activity was recorded against $V$. cholerae.Hence, essential oil from leaves of $P$. roxburghii exhibit great potential for the development of eco-friendly, nontoxic, cost-effective anti-bacterial herbal drug formulations.

Keywords: Pinus roxburghii Sarg., Essential oil, toxicological efficacy, water borne pathogens, etc.

\section{INTRODUCTION}

Pinus roxburghii Sarg. also known as Chir pine, mostly found in Indian sub-continents. Pines are known have largest among all gymnos comprises <250 species (Sonibare \& Olakunle., 2008). P. roxburghii generally found on higher altitude (1200-1850 m) and very chilling temperature with range $5-15^{\circ} \mathrm{C}$ (Siddiquiet al., 1999). Needles are usually $14-16 \mathrm{~cm}$ long. It is a tall and evergreen tree (Sehgal et al., 1995). Microbiological activity research into the EOs on $P$. roxburghii has shown significant antifungal activity (Hassan and Amjid, 2009). Their ethanolic extract of leaves, stem and cones found high potential in anti-microbial properties and used in curing many diseases (Blunt, 2003). This is due to maximum amount of secondary metabolites viz., Ascorbic acid, alkaloids and terpenoids (Judžentienėet al., 2006).Still more investigations are needed to be explored to enlightened its bactericidal and fungicidal properties (Soliman and Badeea, 2002, Jha et al., 2018, Tiwari et al., 2021).
EOs can cause many different actions due to chemically diverse constitution whereas synthetic chemicals are target oriented in nature (Hong et al., 2004; Singh and Agrawal, 2020). Many workers investigated the antifungal activities of essential oil of Pinacea species (Eui et al., 2004; Yang and Clausen, 2007; Motiejūnaitė and Pečiulytė, 2010). Also many species are reported to have antibacterial properties (Parihar et al., 2006; Maciąg, 2007).

Escherichia coli: E. coli, usually found intestinal part of human as well as many other animals. Generally, it does not have pathogenic activity in intestinal part. However, it may cause UTIs, bacteremia etc. in different parts of the body. A few enteropathogenic strains can cause acute diarrhea (Singh et al., 2018; Singh and Agrawal, 2020; Rane and Patel, 2021).

Klebsiella pneumoniae: K. pneumoniae is a Gram negative encapsulated, lactose inciting, facultative anaerobic, rodshaped bacterium. It can cause destructive changes to

*Corresponding author: dakshlabs@gmail.com; rkps91@gmail.com 
human lungs via inflammation and haemorrhage with necrosis that sometimes produces a thick, bloody, mucoid septum. K. pneumoniae infections are most frequently seen in the people with weakened immune system (Singh et al., 2018; Singh and Agrawal, 2020).

Salmonella typhimurium: They are rod-shaped bacteria and unable to ferment lactose. They are the main causative agent of typhoid fever, with incubation period of 3-5 day and may be fatal if untreated. Abdominal pain, fever and vomiting are the main symptoms (WHO, 2008; Singh et al., 2018; Singh and Agrawal, 2020).

Vibrio cholerae: This is a gram negative, commashaped, small bacteria with a polar flagellum. It is the causative agent of cholera. Different strains causes ionic imbalance in intestinal mucosa causing cholera
(WHO, 2008). Watery mucus-flecked stools due to increased peristalses was the initial symptoms. Due to these movements a patient may lose 10-15 liters of fluid in a day. Under sever conditions, untreated patients may die due to heavy dehydration(Singh et al., 2018; Singh and Agrawal, 2020).

\section{MATERIALAND METHOD}

Collection of plant materials: The plant materials of $P$. roxburghii Sarg. were collected from Landour, Mussoorie, Uttarakhand, India(Figure. 1)(Singh et al., 2018, Tripathi et al., 2021). Needles were crushed and hydrolyzed using a Clevenger type Apparatus for 4-6 hours. Essential oil of $P$. roxburghii (pine) was nearly transparent. Oil content was stored at $4^{\circ} \mathrm{C}$ until analysis (Singh et al., 2018; Tripathi et al., 2021).

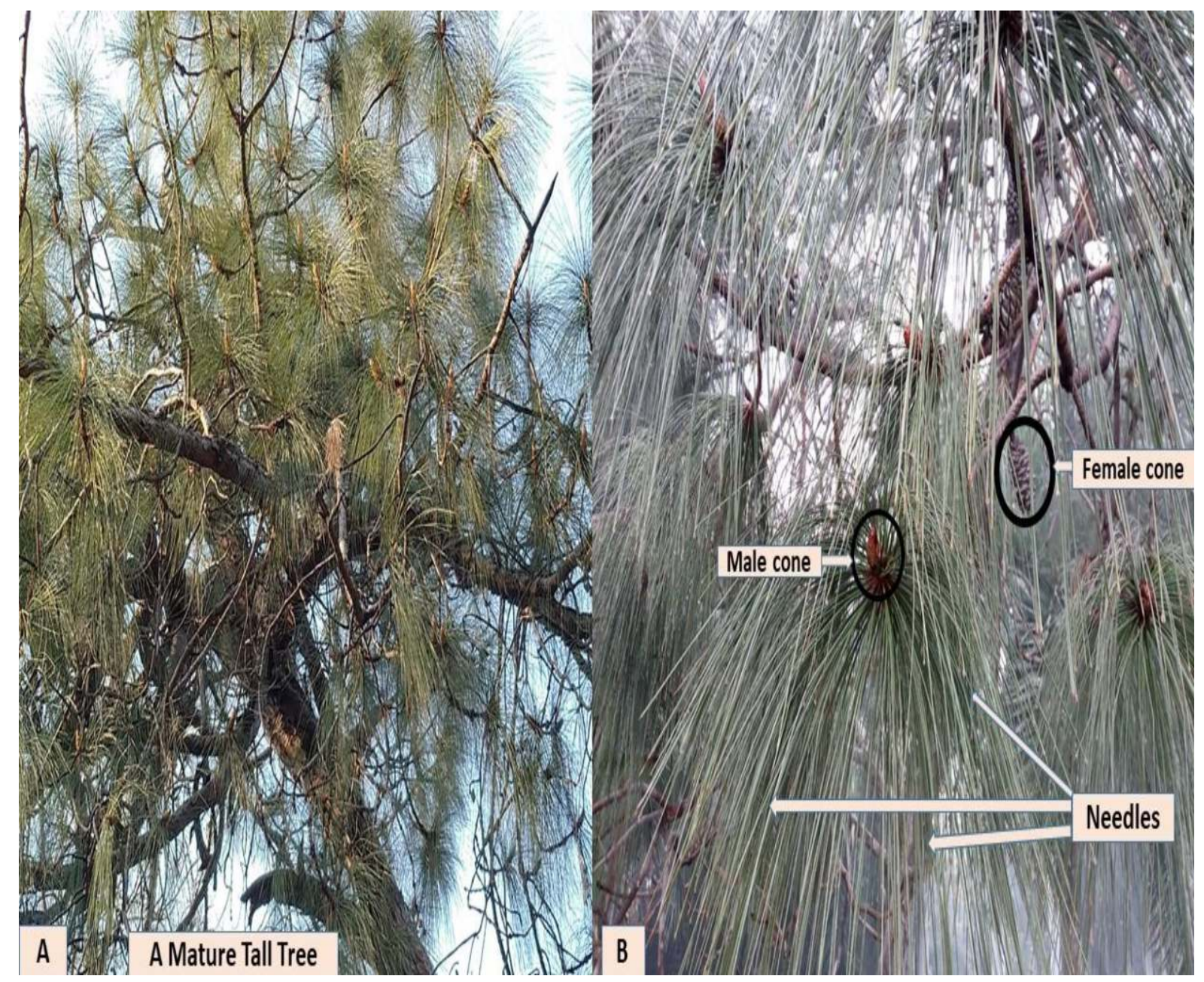

Figure 1. : (A) Mature tree of $P$. roxburghii \& (B) tree with needles, male and female cones. 
Processing of Plant Material: Collected plant material was thoroughly washed and dried at room temperature, under the shade by keeping them onto the blotting papers. These samples were left as such for nearly one month, however regularly examined time to time to avoid any biological contamination. The blotting papers were changed at least once in a week. After completing the drying process, the dried parts were individually crushed into small pieces using pastel and motor and was filled in zip-bag for future process (Singh et al., 2018; Tripathi et al., 2021).

Extraction of Oil from plants using Clevenger apparatus: The oils were extracted as prescribed by Clevenger (1928). Summary of the method used is mentioned below (Singh et al., 2018; Singh and Agrawal, 2020; Mishra et al., 2021):

(I) Fresh vegetal parts (leaves, Stem, seeds etc.) was collected which was washed properly in tap water.

(ii) Plant material was weighed and chopped into small pieces.

(iii) Material was uploaded in Clevenger apparatus for extraction of oil.

(iv) Properly dried vegetal parts was placed in a Clevenger type apparatus for the extraction of EOs by hydrodistillation.

(v) The extracted EOs was stored in anhydrous sodium sulphate in dark at $4^{\circ} \mathrm{C}$, until used.

Antibacterial Screening: Essential oils were screened for antibacterial activity against $E$. coli, $K$. pneumoniae, S. typhimurium and V. cholerae. All the aforementioned bacteria are water borne human pathogens (Jha et al., 2021). Zone of Inhibition (ZOI) were determined using Kirby-Bauer disc diffusion method recommended by Clinical Laboratory Standard Institute (CLSI). Dilutions of the oil were prepared in DMSO. Different concentration of oil were tested using standard disc, which were incubated at 37 ${ }^{\circ} \mathrm{C}$ for 24 hours (Satyal et al., 2012, Singh et al., 2018; Singh and Agrawal, 2020). The final zone of inhibition were recorded after 24 hours. Streptomycin was used as standard drug for this experiment. DMSO was used as a positive control whereas formaldehyde was used as negative control.

\section{RESULTS AND DISCUSSION}

Percent yield: $\%$ yield $=$ weight of oil $/$ weight of sample x 100 (Singh and Agrawal, 2020). The percent yield of EOs was found $0.1407 \%$ of Pinusroxburghii.
At 1000 ppm, the zone of inhibition (ZOI) of essential oil of $P$. roxburghii was $19.5 \mathrm{~mm}$ against $E$. coli (MTCC-723). For 500 ppm, 250 ppm, 125 ppm, 62.5 ppm, 31.25 ppm, 15.625 ppm and 7.8125 ppm; the ZOI was $15 \mathrm{~mm}, 15 \mathrm{~mm}, 9.5 \mathrm{~mm}, 9 \mathrm{~mm}, 10 \mathrm{~mm}, 7 \mathrm{~mm}$ and 7 $\mathrm{mm}$ respectively. No growth was recorded for negative control (Fig 2).

At 1000 ppm, the zone of inhibition (ZOI) of essential oil of $P$. roxburghii was $20 \mathrm{~mm}$ against $K$. pneumoniae. For 500 ppm, 250 ppm, 125 ppm, 62.5 ppm, 31.25 ppm, 15.625 ppm and 7.8125 ppm; the ZOI was 15.5 $\mathrm{mm}, 13 \mathrm{~mm}, 8.5 \mathrm{~mm}, 7 \mathrm{~mm}, 6.5 \mathrm{~mm}, 6 \mathrm{~mm}$ and $9 \mathrm{~mm}$ respectively. No growth was recorded for negative control (Fig 3).

At 1000 ppm, the zone of inhibition (ZOI) of essential oil of $P$. roxburghii was $22 \mathrm{~mm}$ against $S$. typhimurium. For 500 ppm, 250 ppm, 125 ppm, 62.5 ppm, 31.25 ppm, $15.625 \mathrm{ppm}$ and $7.8125 \mathrm{ppm}$; the ZOI was 15 mm, $13 \mathrm{~mm}, 10 \mathrm{~mm}, 7 \mathrm{~mm}, 6.5 \mathrm{~mm}, 6 \mathrm{~mm}$ and $6.5 \mathrm{~mm}$ respectively. No growth was recorded for negative control (Fig 4).

At 1000 ppm, the zone of inhibition (ZOI) of essential oil of P. roxburghii was $10.5 \mathrm{~mm}$ against V. cholerae. For 500 ppm, 250 ppm, 125 ppm, 62.5 ppm, 31.25 ppm, 15.625 ppm and 7.8125 ppm; the ZOI was 8.5 $\mathrm{mm}, 6 \mathrm{~mm}, 6 \mathrm{~mm}, 8 \mathrm{~mm}, 6 \mathrm{~mm}, 6 \mathrm{~mm}$ and $6 \mathrm{~mm}$ respectively. No growth was recorded for negative control (Fig 5).

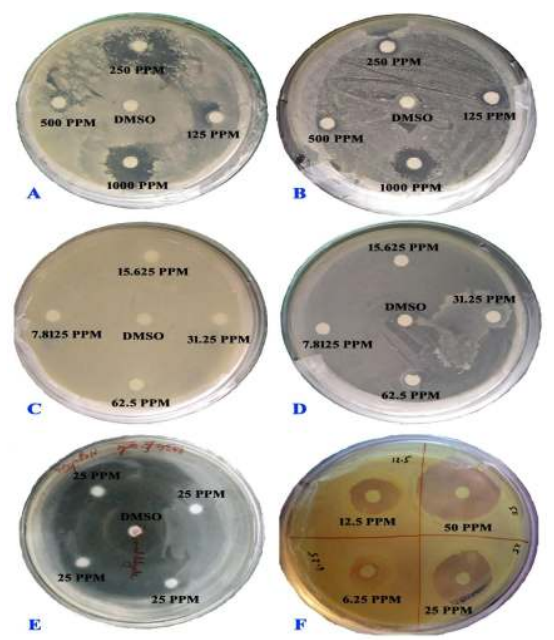

Note: A - D: Pinus oil on E. coli (MTCC-723); E: Negative; F: Standard drug (Streptomycin).

Figure 2: Antibacterial activity of $P$. roxburghii essential oil against E. coli (MTCC-723). 


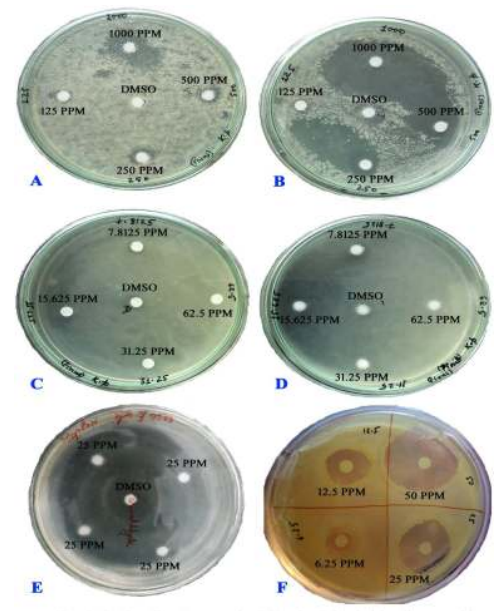

Note: A - D: Pinus oil on K. pneumoniae; E: Negative; F: Standard drug (Streptomycin)

Figure 3: Antibacterial activity of $P$. roxburghii essential oil against K. pneumoniae.
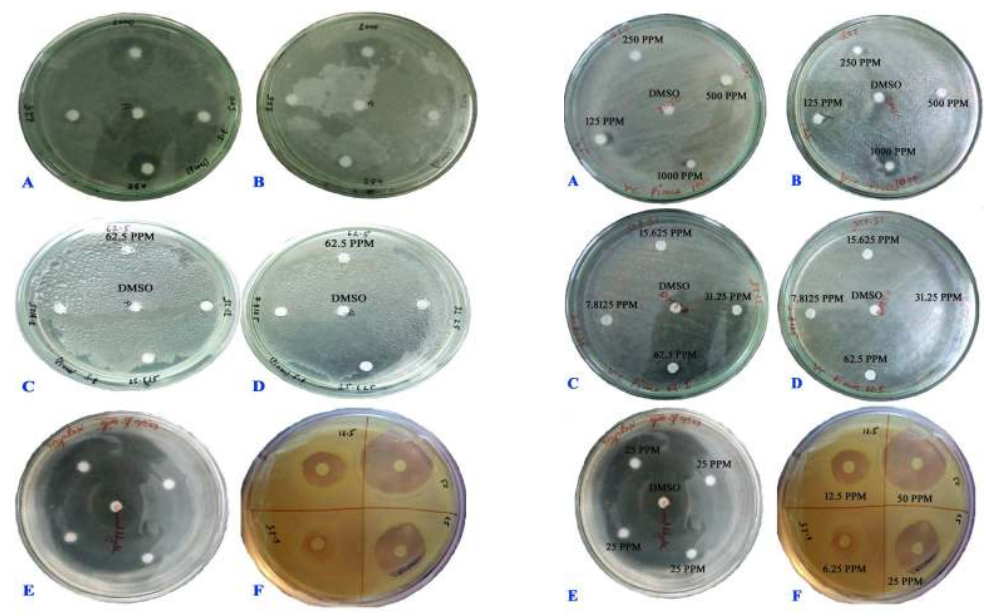

Note: A - D: Pinus oil on S. Note: A - D: Pinus oil on V. typhimurium; F: Standard drug Cholerae; E: Negative; F: Standard (Streptomycin) drug (Streptomycin)

Figure 4: Antibacterial activity of Figure 5: Antibacterial activity of $P$. roxburghii essential oil against $P$. roxburghii essential oil against S. typhimurium. V. cholerae.

Table 1: Mean ZOI values of EO of $P$. roxburghii against bacterial pathogens.

\begin{tabular}{|l|c|c|c|c|c|c|c|c|c|}
\hline $\begin{array}{l}\text { Pinus oil conc. } \\
\text { (in ppm) }>\end{array}$ & 1000 & 500 & 250 & 125 & 62.5 & 31.25 & 15.625 & 7.8125 & DMSO \\
\hline E. coli & 19.5 & 15 & 15 & 9.5 & 9 & 10 & 7 & 7 & 0 \\
\hline K. pneumoniae & 20 & 15.5 & 13 & 8.5 & 7 & 6.5 & 6 & 9 & 0 \\
\hline S. typhimurium & 22 & 15 & 13 & 10 & 7 & 6.5 & 6 & 6.5 & 0 \\
\hline V. cholerae & 10.5 & 8.5 & 6 & 6 & 8 & 6 & 6 & 6 & 0 \\
\hline
\end{tabular}

Note: ZOI (or ZID) value was measured in mm using standard scaling.

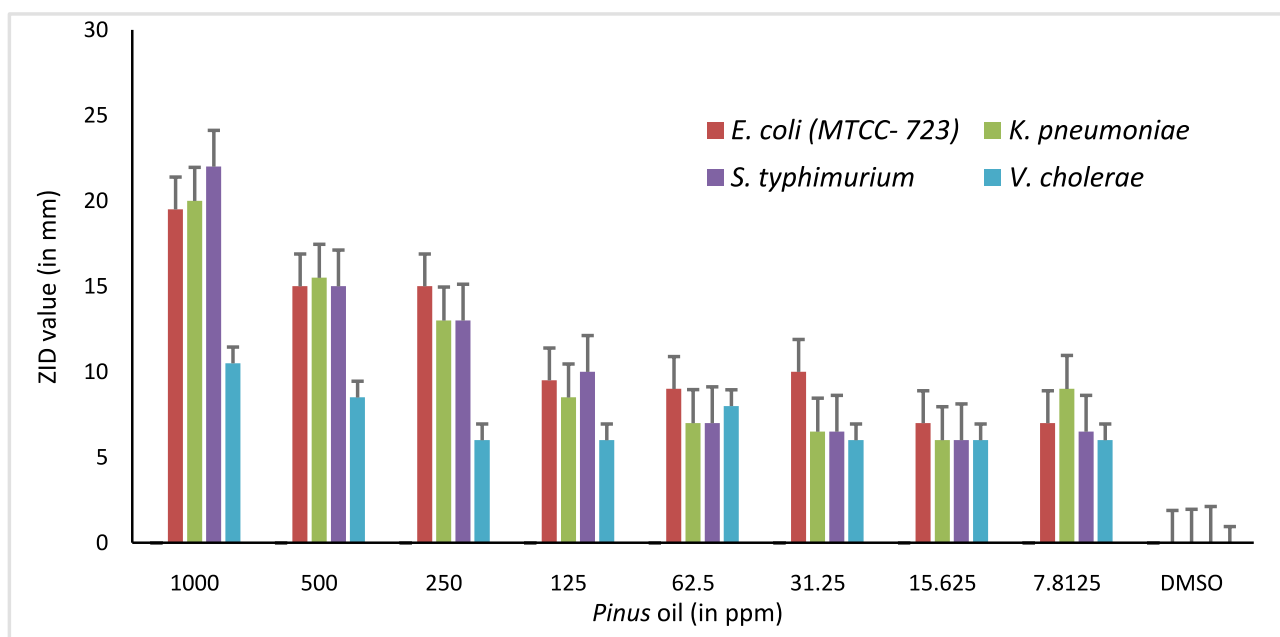

Graph : Toxicological activities of $\mathrm{EO}$ of $\mathrm{P}$. roxburghii against water borne pathogens. 
All the aforementioned bacteria are water borne human pathogens. Pinus roxburghii is the native of adverse climatic condition and hence its EOs have some specific drugs which possess antimicrobial activity. Highest inhibiting activity was recorded against $S$. typhimurium. Inhibiting activity was also found against K. pneumoniae and E. coli (MTCC-723). A very poor result was recorded against $V$. cholerae.

\section{CONCLUSION}

Antibacterial and toxicological efficacy of the EOs of the chir oil was the utmost objective of the present work, which was achieved. After extraction of oil by Clevenger type apparatus, oil was used for toxicological study using Kirby-Bauermethod recommended by CLSI. Highest toxicological efficacy was recorded against $S$. typhimurium whereas minimum against $V$. cholerae. Essential oil of $P$. roxburghii exhibit great potential for the development of eco-friendly, non-toxic, cost-efficient and antibacterial herbal formulations.

\section{ACKNOWLEDGEMENTS}

I would like to give special thanks to Prof. Anupam Dikshit (FNASc.), Director of Biological Product Laboratory (BPL), Department of Botany, University of Allahabad, for providing me laboratory facilities; to Dr. Saket Jha for his valuable suggestions.

\section{REFERENCES}

1. Blunt, E. P. (2003). Aromatherapy in practice. Holistic Nurs. Pract., 17, 329.

2. Eui, J. H., Jeung, N., Choi, G., Kyung, C.,\& Eui, B. J. (2004). Antibacterial and antifungal effects of essential oils from coniferous trees. Biol. Pharm. Bull., 27, 863.

3. Hassan, A., \& Amjid, I. (2009). Gas chromatography-mass spectrometric studies of essential oil of Pinusroxburghaii stems and their antibacterial and antifungal activities. J Med Plant Res., 3, 670-673.

4. Hong, E. J., Na, K. J., Choi, I. G., Choi, K. C., \& Jeung, E. B. (2004). Antibacterial and antifungal effects of essential oils from coniferous trees. Biological and Pharmaceutical Bulletin, 27(6), 863-866.

5. Jha, S., Singh, R., Tiwari, A. K., Tripathi, S. K., Pandey, A.,\& Dikshit, A. (2021). Microbial and physico-chemical analysis of palatable water samples from different localities of Prayagraj district. Biochem. Cell. Arch., 21, 000-000. https://connectjournals.com/03896.2021.21.000

6. Jha, S., Singh, R., Pandey, A., Bhardwaj, M., Tripathi, S. K., Mishra, R. K., \& Dikshit, A. (2018). Bacterial toxicological assay of Calcium Oxide Nanoparticles against some plant growth promoting rhizobacteria. International Journal for Research in Applied Science and Engineering Technology, 6(11), 460-466.

7. Judžentienė, A., Šližytė, J., Stiklienė, A., \& Kupčinskienè, E. (2006). Characteristics of essential oil composition in the needles of young stand of Scots pine (Pinussylvestris L.) growing along aerial ammonia gradient. Chemija, 17(2), 67-73.

8. Maciąg, A., Milaković, D., Christensen, H. H., Antolović, V., \& Kalemba, D. (2007). Essential oil composition and plant-insect relations in Scots pine (Pinus sylvestris L.).

9. Mishra, P., Tripathi, A., Tiwari, V., Jha, S., \& Dikshit, A. (2021). No Choice Bioassay of essential oils extracted from Murrayakoenigii L. and Callistemon citrinus (Curtis) Skeels. againstOdontotermesobesusRambur. J. Exp. Zool. India, 24, 1083-1091. https:// connect journals.com/03895.2021.24.1083.

10. Motiejūnaitè, O., \& Dalia Pečiulytè, D. (2004). Fungicidal properties of Pinus sylvestris L. for improvement of air quality. Medicina (Kaunas), 8, 787-794.

11. Parihar, P., Parihar, L., \& Bohra, A. (2006). Antibacterial activity of extracts of Pinus roxburghii Sarg. Bangladesh J Bot, 35(1), 85-86.

12. Rane H. and Patel R. (2021). Antibiotic susceptibility profile of bacteria from natural sources of rural areas of Nimad, Madhya Pradesh.International Journal of Biological Innovations. 3(2):318-322 https://doi.org/ 10.46505/IJBI.2021.3211,

13. Satyal P, Paudel P, Lamichhane B, Setzer WN. (2012). Volatile constituents and biological activities of the leaf essential of Jasminummesnyi growing in Nepal. J Chem Pharm Res.,4, 437-439.

14. Sehgal, R. N., Chauhan, S. K., \& Dhall, S. P. (1995). Half-sib progeny evaluation in Chir pine. Silvaegenetica, 44(2-3), 61-62. 
15. Siddiqui, K. M., Mohammad, I., \& Ayaz, M. (1999). Forest ecosystem climate change impact assessment and adaptation strategies for Pakistan. Climate Research, 12(2-3), 195-203.

16. Singh, R., Pathak, A., Dikshit, A., \& Mishra, R. K. (2018). Comparision of biological activities of essential oil of three gymnosperms against Salmonella typhimurium. International Journal of Creative Research Thoughts, 6 (1), 1420-1426.

17. Singh, R., \& Agarwal, M. (2020). GC-MS Analysis and Anti-bacterial activity of Juniperus communis L. International Journal of Emerging Technologies and Innovative Research, 7(11), 467- 477. http://www.jetir.org/ papers/ JETIR2011353.pdf.

18. Soliman, K. M., \& Badeaa, R. I. (2002). Effect of oil extracted from some medicinal plants on different mycotoxigenic fungi. Food and chemical toxicology, 40(11), 1669-1675.

19. Sonibare, O. O., \& Olakunle, K. (2008). Chemical composition and antibacterial activity of the essential oil of Pinus caribaea from Nigeria. African Journal of Biotechnology, 7(14).
20. Tiwari, A. K., Jha, S., Agrawal, R., Mishra, S. K., Pathak, A. K., Singh, A. K., Dikshit, A., \& Awasthi, R. R. (2021). Antibacterial efficacy of phyto synthesized zinc oxide nanoparticles using Murrayapaniculata L. leaf extract. International Journal of Pharmaceutical Sciences and Research,13(2), 1000-1009. http://dx.doi.org/ 10.13040/IJPSR.0975-8232.13(2).1000-095.

21. Tripathi, S. K., Jha, S., Dikshit, A.,\& Kumar, R. (2021). Phytochemical and antioxidant assay of Ecliptaalba (L.) leaf extract. International Journal of Pharmaceutical Sciences and Research, 12(4), 2288-2295. http://dx.doi.org/ 10.13040/IJPSR.0975-8232.12(4).2288-95.

22. World Health Organization. (2008). Water (No. WHO/HSE/PHE/AMR/08.01. 01). World Health Organization.

23. Yang, V. W., \& Clausen, C. A. (2007). Antifungal effect of essential oils on southern yellow pine. International biodeterioration \& biodegradation, 59(4), 302-306. 